\title{
The Determinants of Labor Productivity in Jordan During the Period 1980-2017
}

\author{
Elham Mohammad Mustafa Alhaj Yousef \\ Business Economics Department, Faculty of Business, University of Jordan, Amman, Jordan
}

Email address:

Ehajsuper1@hotmail.com

\section{To cite this article:}

Elham Mohammad Mustafa Alhaj Yousef. The Determinants of Labor Productivity in Jordan During the Period 1980-2017. International Journal of Business and Economics Research. Vol. 9, No. 1, 2020, pp. 21-28. doi: 10.11648/j.ijber.20200901.13

Received: December 30, 2019; Accepted: January 9, 2020; Published: January 27, 2020

\begin{abstract}
This study aims at investigating the long-run and short-run relationships between labor productivity in Jordan and each of capital intensity, wages, trade openness and regulatory quality over the period 1980-2017. All the study variables are found to be stationary at the first difference. Johansen cointegration test revealed that there is a unique cointegrating equation. Therefore, Vector Error Correction Model (VECM) was implemented to estimate the short and long-run effects. The empirical results show that capital intensity, wages and regulatory quality have significant long-run positive impact on Jordanian labor productivity. However, all the independent variables have insignificant short-run effects on labor productivity during the study period. The significant negative coefficient of the error correction term (ECT) confirms the existence of long-run relationships. Moreover, this paper highlights the important role of regulatory quality as a governance indicator in improving labor productivity in Jordan, thus the study recommends improving public administration, strengthening governance, and applying the appropriate policies and regulations that promote and enhance national and foreign direct investments, and ensure efficient allocation of resources.
\end{abstract}

Keywords: Capital Intensity, Governance, Labor Productivity, Trade Openness

\section{Introduction}

The slowdown of labor productivity is one of the main economic issues that concerns Jordanian government as well as all governments in the world. It becomes important to explore and analyze the determinants of labor productivity, in order to adopt suitable policies that motivate workforce, enhance and foster labor productivity, which could eventually tackle and face the future economic or financial crises. In fact an increase in labor productivity is essential to improve and boost the economic growth and development within a country [1]. In contrast, low labor productivity will worsen living standards and exacerbate government deficit.

Jordan is one of the smallest economies in the Middle East [2], and it is attractive to foreign investors based upon its skilled workforce and progressive economic liberalization. Its economy depends on mining, manufacturing, construction, and power generation. Jordan is one of the largest producers and exporters of Phosphate in the world. The main industrial products are potash, phosphates, cement, clothes, pharmaceutical products and fertilizers. However, the lack of its natural resources, increasing inflows of refugees, widespread corruption, excessive bureaucracy and regional political turmoil have impeded its economic growth and increased the rates of unemployment and poverty. Jordanian public debt has increased to about 96\% of GDP in 2017. Therefore, Jordanian government issued an income tax law in the context of an IMF financial reform program in an attempt to reduce such public debt [3].

Jordan's economy is relatively diversified. The annual reports of Central Bank of Jordan revealed that the services sector dominates the Jordanian economy; agriculture accounts for only $4.4 \%$ of its GDP; mining and manufacturing contribute to $21 \%$, while services sector constitutes nearly $74.6 \%$ of its GDP. The great reliance on services sector and the dependency of such economy on foreign aids and remittances rendered it vulnerable to external economic, financial or political shocks [3]. Furthermore, there are many factors that cause Jordan to suffer from low and deteriorating labor productivity, especially after 2008 financial crisis, such as the scarcity of skilled labor, misallocation of resources, overworking effects, 
low wages, corruption, foreign capital flight, etc. Therefore, exploring, understanding and analyzing the relationship between these factors and the labor productivity are crucial and could enable policy makers to manage and enhance the current labor productivity relating to the determinants identified in this paper, increase the efficiency of resources utilization and ultimately improve the economic growth and social welfare.

\section{The Problem of the Study}

Labor productivity is an essential factor of economic growth in any country. Disappointingly, Jordan suffers from low growth rates of its gross domestic product (GDP) and faces challenges and pressures to get its economy functioning in a healthy manner $[2,4,5]$. It also suffers from relatively low labor productivity due to its government policies and regulations that failed to encourage and attract long term national and foreign investments as well as to adopt new technologies, which consequently deteriorate its economic growth [6]. Therefore, exploring and analyzing the impact of macroeconomic variables such as, capital intensity, wages, human capital, trade openness and governance on labor productivity would reveal the causes of poor labor productivity in Jordan. Thus, this paper tries to answer the following general question: what are the main factors that could significantly affect the labor productivity in Jordan? Specifically: how capital intensity, wages, human capital, trade openness and governance indicator affect labor productivity in Jordan?

\section{Objective of the Study}

The study aims at investigating the long-run and short-run relationships between labor productivity in Jordan and each of: capital intensity, wages, human capital, trade openness and governance indicator.

\section{The Importance of the Study}

In spite of various studies conducted to investigate the determinants of labor productivity in individual economic sectors in Jordan, there are few studies conducted to analyze the impact of several macroeconomic variables on labor productivity in Jordanian economy as a whole. Therefore, this paper investigates the short-run and long-run effects of five macroeconomic variables (capital intensity, human capital, trade openness, wages and governance indicator) on labor productivity in Jordan. Thus, the outcomes of this study are valuable and could help policy makers in Jordan to improve the current labor productivity relating to the macroeconomic variables, and consequently boost the economic growth and living standards.

\section{Limitations of the Study}

There are many factors that can affect labor productivity in
Jordan, such as; working conditions, company policies, payment delay, discontinuity of work, relaxation allowances, poor planning and scheduling, material and/or equipment shortage, job security, work satisfaction, old equipment, etc..., but such factors have subjective and non-precise indicators. Moreover, the unavailability of all required data for such factors during the study period forced the study to ignore them. Therefore, this study is limited to investigate the impact of only the above mentioned five macroeconomic variables on labor productivity in Jordan.

\section{Theoretical and Empirical Literature Review}

In economic theory, the higher the wages the higher the labor productivity $[7,8]$, because higher wages leads to greater labor cost, which in turn directs firms to substitute capital for labor, this will consequently increase the marginal labor productivity. Based on the efficiency wages theory, Kumar and Wakeford stressed that the higher wages would increase the opportunity cost of job loss and ultimately would motivate workers to improve their productivities [7, 9]. In fact, a significant positive relationship was found in many previous studies [9-16]. On the other hand, some studies found that increasing wages more than the market clearance level is unable to achieve the desirable labor productivity level $[17,18]$. These studies assured that the impact of higher wages on quit and fire rates is little to be consistent with the efficiency wage argument. In fact, the classical economic theory confirmed that wages are paid according to the marginal productivity of labor under perfect competition. However, due to the financial crisis of 2008 and its slow recovery afterwards, both employment and demand of labor decreased, which in turn made labors only want to retain their jobs and improve their productivities even their paid wages are lowered $[16,19]$. In other words, the crisis of 2008 results in an inverse relationship or weak positive one between labor productivity and wages, because workers need to retain their jobs during recession. Furthermore, Tsoku and Matarise found a positive relationship between wages and labor productivity in the short-run with no effect in the longrun, because labor productivity will initially rise with the increase of wages and capital/labor ratio, and then it will readjust back to the original level as does the capital/labor ratio [20].

The endogenous economic growth theory has emphasized that economic and productivity growth is achieved by investing in human capital, knowledge, infrastructure, and research and development, and not by depending on exogenous variables [21, 22, 23]. The advocators of endogenous growth theory have argued that economies could benefit from the rapid transfer of new technologies as well as the highly educated, trained and skilled workers who are able to adapt such technologies to the local needs [24]. Welleducated and highly skilled and trained workers know the operations of new machines and technology, which 
ultimately improve the output quality, lower the production cost per unit and improve productivity. Several previous studies have actually proved the significant positive relationship between human capital and labor productivity [25-30]. On the other hand, Nurudeen and Usman found a negative relationship between human capital and labor productivity because government expenditure on education was not properly utilized by authorities [31]. Fallahi also found an inverse relationship between human capital and labor productivity because of the inefficient, improper, or traditional training that was provided by the firms, thus labors were not able to perform their skills effectively without a good proper training on the newly adopted technology [32]. Spending on education and training might take time to capture its positive impact and this fact could explain the contradictory results in the previous studies. Furthermore, training could serve other objectives such as career prospects, salary or working position instead of labor productivity.

Diffusion of technology (know-how) is achieved through foreign direct investment [23, 33, 34]. Such investment is facilitated by trade openness [23]. Trade liberalization could encourage and enhance foreign competition, improve the productivity of domestic industry, and accelerate accumulation of fixed and human capital and superior technological transfer, resulting in efficient allocation of resources and higher economic growth [35]. Adam Smith emphasized that international trade could boost economic growth by increasing the size of markets, and offering each country the possibility of taking advantage of the increasing returns to scale based on the division of labour and specialization. The classical Ricardian model suggested that comparative advantage could be derived from exogenous technological differences. On the other hand, Hecksher-Ohlin model suggested that it could be derived from different factor endowments, but both models have agreed that international trade openness has a positive impact on economic growth and development [36]. Various empirical studies have found a significant positive relationship between trade openness and economic growth measured by GDP growth rate or per capita GDP growth rate [37-40]. In fact, neoclassical growth theory has considered savings then capital accumulation (measured by capital/labor ratio) as crucial needs to achieve economic growth [41-43]. Brems believed that increasing capital stock formation could enhance and improve productivity levels [42].

On the other hand, Smith affirmed the vital role of regulations, policies and institutions in the allocation of resources [44]. He stressed that some policies and regulations made by relevant authorities could inefficiently allocate resources, reduce factors' productivity and increase costs of production. Similarly, Barro emphasized that policies and institutions are deemed to play a critical role in accelerating economic growth in the long-run [45, 33, 46]. In addition, Barro affirmed that improvement in the rule of law, government policies and terms of trade could have significant positive effects on per capita real GDP growth rate [46].
Lahouij also emphasized that implementing unsound economic policies that give the governing elite unrestricted power over the allocation of national resources can make the country suffers an exacerbated corruption, which consequently lead to a high absence of accountability and a decline in productivity and economic growth [47]. In fact, previous studies showed mix results for the relationship between labor productivity and macroeconomic variables, depending on the selected study period and the political, social and economic conditions prevailing in each individual country covered in such studies. These contradictory outcomes can also be occurred because of the regional differences that arise from differences in the level of investments and concentration of high quality labor, for instance, rural areas often have lower labor productivity comparatively to urban ones as the level and the quality of investments and labor force in urban areas are higher.

\section{Methodology, Data Sources and Variables Description}

The study uses time series data for Jordan on annual basis over the period 1980-2017. The study model is based on the following Cobb Douglas production function that relates the amounts of production inputs to the amount of output:

$$
\mathrm{Y}=\mathrm{f}(\mathrm{K}, \mathrm{L})
$$

Where Y represents the output level (real GDP), K represents the amount of capital, and $L$ represents the amount of labor or number of workers. Dividing both sides by $L$ to get:

$$
\mathrm{Y} / \mathrm{L}=\mathrm{f}(\mathrm{K} / \mathrm{L}, 1)=\mathrm{f}(\mathrm{K} / \mathrm{L})
$$

Labor productivity $(\mathrm{Y} / \mathrm{L})$ is the amount of output (or real GDP) produced by worker. Equation 2 means that the average productivity of labor $(\mathrm{Y} / \mathrm{L})$ is a function of real capital intensity per labor $(\mathrm{K} / \mathrm{L})$. After adding other four independent variables to equation 2 , it becomes:

$$
\mathrm{Y} / \mathrm{L}=\mathrm{f}(\mathrm{K} / \mathrm{L}, \mathrm{W}, \mathrm{HC}, \mathrm{TO}, \mathrm{RQ})
$$

Taking the logarithm of both sides leads to the following equation:

$$
\begin{array}{r}
\log (\mathrm{Y} / \mathrm{L})_{\mathrm{t}}=\log \mathrm{A}+ \\
\beta_{1} \log (\mathrm{K} / \mathrm{L})_{\mathrm{t}}+\beta_{2} \log \mathrm{W}_{\mathrm{t}}+\beta_{3} \log \mathrm{HC}_{\mathrm{t}}+ \\
\beta_{4} \log \mathrm{TO}_{\mathrm{t}}+\beta_{5} \operatorname{logR\mathrm {R}_{\mathrm {t}}}
\end{array}
$$

Where A represents the technology level, W: average monthly real wages per worker, TO: trade openness, RQ: regulatory quality as the governance indicator. HC: Human capital measured by Human Development Index is obtained from United Nations Development Program, and it is a composite index of life expectancy at birth (health), Knowledge (education) and per capita income (standard of living) indicators that varies between 0 (the lowest) and 1 (the highest) human development. Y and $\mathrm{K}$ are obtained from the bulletins of Central Bank of Jordan. L and $\mathrm{W}$ are 
extracted from the bulletins of the General Department of Statistics in Jordan, while TO and RQ are extracted from World Bank Database. Trade openness is a proxy of economic policies that either invite or restrict trade between countries, and it is actually measured by various methods, but this study uses the sum of exports and imports to GDP ratio. On the other hand, regulatory quality is a governance indicator that measures the ability of the government to design and implement sound policies and regulations that promote private sector development. This indicator varies between -2.5 (the weakest) and 2.5 (the strongest) governance performance.

It is also necessary to add a dummy independent variable (D) that represents the occurrence of the sharp drop in Jordanian dinar in 1989. This crisis may conceal or distort the real effects of the previous macroeconomic variables on the labor productivity in Jordan.

$\mathrm{D}=1$ for the year 1989

$$
=0 \text { otherwise }
$$

If $\log A=\beta_{0}$, then the econometric model to be estimated will be:

$$
\begin{aligned}
& \log (\mathrm{Y} / \mathrm{L})_{\mathrm{t}}=\beta_{0}+\beta_{1} \log (\mathrm{K} / \mathrm{L})_{\mathrm{t}}+\beta_{2} \log \mathrm{W}_{\mathrm{t}}+\beta_{3} \log \mathrm{HC}_{\mathrm{t}}+ \\
& \beta_{4} \log \mathrm{TO}_{\mathrm{t}}+\beta_{5} \log \mathrm{RQ}_{\mathrm{t}}+\gamma \mathrm{D}_{\mathrm{t}}+\mathrm{e}_{\mathrm{t}}
\end{aligned}
$$

Where $\beta_{0}$ : constant or intercept, and $\mathrm{e}_{\mathrm{t}}$ : error term.

\section{Empirical Analysis and Results}

The empirical analysis begins with the unit root tests. The study uses a commonly used augmented Dickey Fuller test (ADF) in order to avoid spurious relationships and test for the existence of unit roots in the time series [48]. ADF statistic is a negative number, and the more negative it is, the stronger the rejection of the null hypothesis of the existence of a unit root in a time series sample. In another way, if the probability value of such statistic is less than 0.05 , the null hypothesis will be rejected, meaning that the variable is stationary at level, but if it is more than 0.05 , the null hypothesis will not be rejected, meaning that the variable is not stationary at level. The results of ADF tests for the study variables are presented in table 1. As shown in table 1, all the variables are not stationary at level, but they are stationary at

\begin{tabular}{|c|c|c|c|c|c|c|c|c|}
\hline \multirow[t]{3}{*}{ Variable } & \multicolumn{4}{|c|}{ Intercept } & \multicolumn{4}{|c|}{ Trend \& intercept } \\
\hline & \multicolumn{2}{|c|}{ Level } & \multicolumn{2}{|c|}{ First difference } & \multicolumn{2}{|c|}{ Level } & \multicolumn{2}{|c|}{ First difference } \\
\hline & t-stat & p-value & t-stat & p-value & t-stat & p-value & t-stat & p-value \\
\hline $\mathrm{Y} / \mathrm{L}$ & -2.2622 & 0.1891 & -5.2748 & 0.0001 & -0.6121 & 0.9723 & -4.4171 & 0.0065 \\
\hline $\mathrm{K} / \mathrm{L}$ & -3.8201 & 0.0071 & -3.3642 & 0.0191 & -1.6293 & 0.7561 & -4.4020 & 0.0066 \\
\hline W & -1.1370 & 0.6907 & -5.8640 & 0.0000 & -2.2259 & 0.4620 & -5.7346 & 0.0002 \\
\hline TO & -3.0836 & 0.0368 & -5.0692 & 0.0002 & -3.0471 & 0.1342 & -4.9720 & 0.0015 \\
\hline $\mathrm{HC}$ & -1.3855 & 0.5785 & -3.4782 & 0.0153 & -1.4834 & 0.8169 & -3.5578 & 0.0499 \\
\hline
\end{tabular}
first difference either at $1 \%$ or $5 \%$ significance level.

Table 1. ADF unit root tests results.

Author's calculations using Eviews.

Multicollinearity problem is actually included between human development index (HC) and wages (W) since the latter indicates per capita income in addition to the health care level that individual enjoys (the correlation between $\mathrm{HC}$ and $\mathrm{W}$ is found to be 0.92). Therefore, human capital measured by such index is removed from econometric equation 5 , and the study model will be as follows:

$$
\begin{array}{r}
\log (\mathrm{Y} / \mathrm{L})_{\mathrm{t}}=\alpha_{0}+\alpha_{1} \log (\mathrm{K} / \mathrm{L})_{\mathrm{t}}+\alpha_{2} \log \mathrm{W}_{\mathrm{t}}+\alpha_{3} \log \mathrm{TO}_{\mathrm{t}}+ \\
\alpha_{4} \log \mathrm{RQ}_{\mathrm{t}}+\gamma \mathrm{D}_{\mathrm{t}}+\mathrm{e}_{\mathrm{t}}
\end{array}
$$

The second step in this analysis is determining the optimal

\begin{tabular}{|c|c|c|c|c|c|c|}
\hline Lag & $\log \mathbf{L}$ & LR & FPE & AIC & SC & HQ \\
\hline 0 & 67.52628 & NA & $4.51 \mathrm{e}-06$ & -3.795663 & -3.660984 & -3.749734 \\
\hline 1 & 215.1762 & $260.5587 *$ & $1.30 \mathrm{e}-09 *$ & $-11.95154 *$ & $-11.41283 *$ & $-11.76782 *$ \\
\hline 2 & 221.1523 & 9.491423 & $1.57 \mathrm{e}-09$ & -11.77366 & -10.83091 & -11.45216 \\
\hline 3 & 229.9512 & 12.42200 & $1.65 \mathrm{e}-09$ & -11.76184 & -10.41505 & -11.30254 \\
\hline 4 & 237.3753 & 9.170963 & $1.94 \mathrm{e}-09$ & -11.66914 & -9.918311 & -11.07205 \\
\hline
\end{tabular}
lag length for this model as presented in table 2. According to this table, all criteria determined the optimal lag length of one.

Table 2. Lag order selection criteria.

* indicates the optimal lag length selected by the criterion.

LR: sequential modified LR test statistic (each test at $5 \%$ level).

FPE: Final prediction error.

AIC: Akaike information criterion.

SC: Schwarz information criterion.

HQ: Hannan-Quinn information criterion.

The next step is performing Johansen Cointegration Test, the results of such test is presented in table 3 . This table reveals that the probability value for testing the null hypothesis of no cointegrating equations is less than 0.05 (significant) which means the rejection of such hypothesis. However, the probability value for the null hypothesis of 
existing at most 1 cointegrating equation is more than 0.05 one cointegrating equation at 5\% significance level.

(insignificant), which means the acceptance of existing only

Table 3. Results of Johansen Cointegration Test.

\begin{tabular}{llll}
\hline Hypothesized No. of CE (s) & Eigenvalue & Trace Statistic & 0.05 Critical Value \\
\hline None * & 0.470926 & 36.98628 & 29.79707 \\
At most 1 & 0.310332 & 14.06770 & 15.49471 \\
At most 2 & 0.019040 & 0.692059 & 3.841466 \\
\hline
\end{tabular}

Trace test indicates 1 cointegrating eqn (s) at the 0.05 level.

* denotes rejection of the hypothesis at the 0.05 level. **MacKinnon-Haug-Michelis (1999) p-values.

Unrestricted Cointegration Rank Test (Maximum Eigenvalue).

Unrestricted Cointegration Rank Test (Trace).

\begin{tabular}{llll}
\hline Hypothesized No. of CE (s) & Eigenvalue & Max-Eigen Statistic & 0.05 Critical Value \\
\hline None * & 0.470926 & 22.91858 & 21.13162 \\
At most 1 & 0.310332 & 13.37564 & 14.26460 \\
At most 2 & 0.019040 & 0.692059 & 3.841466 \\
\hline
\end{tabular}

Max-eigenvalue test indicates 1 cointegrating eqn(s) at the 0.05 level. * denotes rejection of the hypothesis at the 0.05 level. $* *$ MacKinnon-Haug-Michelis (1999) p-values.

Based on the previous results, VECM is used in order to estimate the cointegrating equation. The results of VECM estimates are presented in table 4 . Regarding table 4, there is a long-run causality running from each variable to labor productivity, and about $9.61 \%$ of the previous year's deviation from long-run equilibrium is corrected in the current year. The significant ECT confirms the existence of long-run relationships, i.e. 0.0961 is the adjustment coefficient or the adjustment speed (the coefficient of ECT (-1)), and it is significant at 5\% significance level (t critical value for the model is 2.06 at $5 \%$ level). The significant long-run elasticities carry the correct expected signs which are consistent with the economic theory and the results of previous studies. The coefficient of ECT (-1) also has the correct sign. Regulatory quality (RQ) has the highest significant long-run positive effect on the average labor productivity (with elasticity of about 0.024 ), while wages (W) has the lowest one (0.0127). In fact, Bolaky and Freund argued that excessive regulations in a country could restrict its economic growth even with the existence of trade openness, because such regulations will distort the allocation of resources, and prevent them from moving into the most productive sectors and to the most efficient firms within sectors. As a result, the increased trade in this country would occur in the "wrong" goods in which it does not have comparative advantages, and this adversely affect labor productivity [49].

Moreover, trade openness (TO) has insignificant effect in both short and long-run. This can be explained by the heavily dependence of Jordanian revenues on exporting natural raw materials and the great reliance on importing consumer goods under free trade agreements, which are responsible for high losses of jobs in production sectors, and for a reduced reliance on domestic goods. Furthermore, some studies found that the quality and the variation of exports matter; trade openness could have a negative effect when the country specializes in low quality products and when it has low variety of exports [50]. Razmi and Refaei also affirmed that the positive impact of trade openness is conditional upon the presence of international knowledge (or new technologies) spillover, without which trade liberalization could have negative effects [39].

The short-run relationships are insignificant. It seems that the variations in the independent variables affect the average product of labor only in the long-run and their effects do not significantly appear in the short-run; for example, increasing capital intensity and trade liberalization may need upgrading of labor skills which often need a long time. It is also clear that there is a significant negative impact of the sharp drop in Jordanian dinar in 1989 (D) on labor productivity by about $0.002 \%$.

The regression of the underlying VECM fits well at $\mathrm{R}^{2}=$ $41 \%$ and adjusted- $\mathrm{R}^{2}=24 \%$. The model also passes the residuals' diagnostic tests against autocorrelation, normality and heteroskedasticity as shown in table 5. The p-value of each test in this table is above 5\% (statistically insignificant) which means the acceptance of the null hypotheses of no autocorrelation, normally distributed residuals, and no heteroskedasticity respectively.

Table 4. VECM estimates $(\Delta(\log (Y / L))$ is the dependent variable, t critical value is 2.06).

\begin{tabular}{llll}
\hline The variables & The long-run elasticity & Standard error & t- statistics \\
\hline Log K/L (-1) & 0.021098 & 0.00988 & 2.13543 \\
Log W (-1) & 0.012735 & 0.00317 & 4.01375 \\
Log RQ (-1) & 0.023658 & 0.00437 & 5.41491 \\
Log TO (-1) & -0.005070 & 0.00985 & -0.51495 \\
\hline \multicolumn{4}{l}{} \\
\hline
\end{tabular}




\begin{tabular}{|c|c|c|c|c|}
\hline & The short-run elasticity & Standard error & t-statistics & \\
\hline$\Delta \log (\mathrm{k} / \mathrm{L})$ & 0.001450 & 0.00417 & 0.34736 & Insignificant \\
\hline$\Delta \log (\mathrm{W})$ & 0.013299 & 0.00803 & 1.65599 & Insignificant \\
\hline$\Delta \log (\mathrm{RQ})$ & 0.000721 & 0.00166 & 0.43402 & Insignificant \\
\hline$\Delta \log (\mathrm{TO})$ & 0.000414 & 0.00262 & 0.15808 & Insignificant \\
\hline $\mathrm{D}$ & -0.002177 & 0.00081 & -2.68017 & Significant at $5 \%$ \\
\hline
\end{tabular}

Author's calculations using Eviews. $\mathrm{R}^{2}=41 \%$, adjusted $\mathrm{R}^{2}=24 \%$.

The long-run model: $\mathrm{ECT}_{\mathrm{t}-1}=\left[\log \mathrm{Y} / \mathrm{L}_{\mathrm{t}-1}-0.021098 \operatorname{LogK} / \mathrm{L}_{\mathrm{t}-1}-0.012735 \log \mathrm{W}_{\mathrm{t}-1}-0.023658 \operatorname{LogRQ} \mathrm{t}_{\mathrm{t}-1}+0.005070 \operatorname{LogTO}_{\mathrm{t}-1}-0.047964\right]$.

Table 5. Summary of the residual tests.

\begin{tabular}{lll}
\hline Residual test & Statistics & Prob. \\
\hline Serial correlation LM test & LM statistics: 23.47715 & 0.9465 \\
Normality test & Jarque-Bera: 11.96576 & 0.4484 \\
Heteroskedasticity White test & Chi-sq: 285.9099 & 0.8790 \\
\hline
\end{tabular}

Author's calculations using Eviews.

\section{Conclusions}

The study has utilized VECM to examine the long and short-run relationships between labor productivity from one side and capital intensity, trade openness, wages and regulatory quality from the other side. The results through using Jordan' annual data over the period 1980-2017, reveals that capital intensity, wages and regulatory quality are very important in explaining labor productivity as they have significant positive effects on it in the long-run. In addition, governance and institutional factors (represented by regulatory quality) were found to be overwhelming factors and responsible for the major contribution to labor productivity in Jordan.

\section{Recommendations}

The empirical results presented in this paper indicate that Jordan needs stronger governance than the conventional determinants of its labor productivity, i.e. this country needs improving public administration, real institutional reforms, designing and applying the appropriate policies and regulations in order to promote and enhance national and foreign direct investments, and to ensure that all resources are efficiently and effectively utilized in pursuit of sustainable economic growth. Foreign and domestic investors are actually basing their investment decisions on applied good governance. The empirical evidence of this study also suggests enhancing trade liberalization that permits new technologies and innovation transfer needed for upgrading labor skills as well as improving both labor and capital productivities.

\section{References}

[1] Freeman, R. (2008). Labour Productivity Indicators. OECD Publications, Division of Structural Economic Statistics, July $2008 . \quad$ http://www.oecd.org/employment/labourstats/41354425.pdf.

[2] International Monetary Fund (2018). Opportunity for All: Promoting Growth and Inclusiveness in the Middle East and
North Africa. Middle East and Central Asia Department, IMF Departmental Paper No. 18/11 (Washington, DC). https://www.imf.org/en/Publications/Departmental-PapersPolicy-Papers/Issues/2018/07/10/Opportunity-for-All Promoting-Growth-and-Inclusiveness-in-the-Middle-Eastand-North-Africa-45981.

[3] International Labour Organization (2018). Decent Work Country Programme: Hashemite Kingdom of Jordan/International Labour Office. - Geneva: ILO, 2018, pp. 1-44. https://www.ilo.org/wcmsp5/groups/public/--arabstates/---ro-

beirut/documents/genericdocument/wcms_656566.pdf.

[4] Abdul-khaliq, S., Soufan, T. and Shihab, R. (2013). Intensive Economic Growth in Jordan during 1978-2010. International Journal of Business and Management, 8 (12), pp. 143-154.

[5] AL-Raimony, A. (2011). The Determinants of Economic Growth in Jordan. Abhath Al-Yarmouk, Humanities and Social Sciences Series, 27 (3), pp. 2297-2305.

[6] International Labour Organization (2013). Decent Work Country Profile: Hashemite Kingdom of Jordan / International Labour Office. - Geneva: ILO, 2013, pp. 1-136. https://www.ilo.org/wcmsp5/groups/public/---dgreports/--integration/documents/publication/wcms_232764.pdf.

[7] Wakeford, J. (2004). The Productivity-Wage Relationship in South Africa: An Empirical Investigation. Development Southern Africa, Paper prepared for the TIPS/DPRU Conference, Johannesburg, September 200321, pp. 109-132. https://www.researchgate.net/publication/227610895_The_produ ctivity-

wage_relationship_in_South_Africa_An_empirical_investigation.

[8] Gordon, R. J. (1997). Productivity, Wages and Price Inside and Outside of Manufacturing in the U.S., Japan, and Europe. National Bureau of Economic Research Working Paper, 2070, pp. 1-73. https://www.nber.org/papers/w2070.

[9] Kumar, S., Webber, D. J. and Perry, G. (2009). Real Wages, Inflation and Labour Productivity in Australia. Department of Business Economics, Auckland University of Technology, New Zealand, pp. 1-15. https://mpra.ub.unimuenchen.de/19293/1/MPRA_paper_19293.pdf.

[10] Tamasauskiene, Z. and Stankaityte, A. (2013). Evaluating of the Relationship between Wages and Labor Productivity in Lithuania: Territorial and Sectoral Approaches. Social Research, 1 (30), pp. 24-35.

[11] Goh, S. K. and Wong, K. N. (2010). Analysing the Productivity-Wage-Unemployment Nexus in Malaysia: Evidence from the Macroeconomic Perspective. Discussion paper 12/10. Melbourne: Monash University. https://www.researchgate.net/publication/46443073_Analyzin g the_Productivity-Wage-

Unemployment_Nexus_in_Malaysia_Evidence_from_the_Ma croeconomic_Perspective. 
[12] Narayan, P. K. and Smyth, R. (2009). The Effect of Inflation and Real Wages on Productivity: New Evidence from a Panel of G7 Countries. Applied Economics, 41 (10), pp. 1285-1291.

[13] Erenburg, S. J. (1998). Productivity, Private and Public Capital, and Real Wage in the US. Applied Economics Letters, 5 (8), pp. 491-495.

[14] Huizinga, F. and Broer, P. (2004). Wage Moderation and Labour Productivity. CPB Netherlands Bureau for Economic Policy Analysis, pp. 1-36. https://ideas.repec.org/p/cpb/discus/28.html.

[15] Nayak, S. R. and Patra, S. (2013). Wage-Labour Productivity Relationship in Manufacturing Sector of Odisha: An Observed Analysis. International Journal of Engineering Science Invention, 2 (3), pp. 8-11.

[16] Trpeski, P., Eftimov, L. and Cvetanoska, M. (2016). Labor Productivity and Real Wages in Macedonia: An Overview Before and After the Global Economic Crisis. European Scientific Journal, 12 (10), pp. 1-14.

[17] Powell, I., Montgomery, M. and Cosgrove, J. (1994). Compensation Structure and Establishment Quit and Fire Rates. Industrial Relations: A Journal of Economy and Society, 33 (2), pp. 229-248.

[18] Krueger, A. B. and Summers, L. H. (1987). Reflections on the Inter-Industry Wage Structure. NBER Working Paper, 1968, pp. 48-81. https://www.nber.org/papers/w1968.

[19] Romei, V. (2017). How Wages Fell in the UK While the Economy Grew. Financial Times. https://www.ft.com/content/83e7e87e-fe64-11e6-96f8$3700 \mathrm{c} 5664 \mathrm{~d} 30$ ? $\mathrm{mhq} 5 \mathrm{j}=\mathrm{e} 2$.

[20] Tsoku, J. T. and Matarise, F. (2014). An Analysis of the Relationship between Remuneration (Real Wage) and Labour Productivity in South Africa. Journal of Educational and Social Research, 4 (6), pp. 1-10.

[21] Romer, P. M. (1986). Increasing Returns and Long-Run Growth. Journal of Political Economy, 94 (5), pp. 1002-1037.

[22] Arrow, K. (1962). Economic Welfare and the Allocation of Resources for Invention. The Rate and Direction of Inventive Activity: Economic and Social Factors. National Bureau of Economic Research, pp. 609-626. https://www.nber.org/chapters/c2144.pdf.

[23] Pack, H. (1994). Endogenous Growth Theory: Intellectual Appeal and Empirical Shortcomings. American Economic Association, 8 (1), pp. 55-72.

[24] Becker, G. S. (1964). Human Capital: A Theoretical and Empirical Analysis with Special Reference to Education. New York: National Bureau of Economic Research. https://www.academia.edu/35396287/HUMAN_CAPITAL_A Theoretical and Empirical Analysis with Special Referen ce_to_Education_THIRD_EDITION.

[25] Aggrey, N., Eliab, L. and Joseph, S. (2010). Human Capital and Labor Productivity in East African Manufacturing Firms. Current Research Journal of Economic Theory, 2 (2), pp. 4854.

[26] Afrooz, A., Rahim, K. B. A., Noor, Z. B. M. and Chin, L. (2010). Human Capital and Labor Productivity in Food Industries of Iran. International Journal of Economics and Finance, 2 (4), pp. 47-51.
[27] Arvanitis, S. and Loukis, E. N. (2009). Information and Communication Technologies, Human Capital, Workplace Organization and Labour Productivity: A Comparative Study Based on Firm-Level Data for Greece and Switzerland. Information Economics and Policy, 21 (1), pp. 43-61.

[28] Banerjee, R. and Wilson, J. K. (2015). Roles of Education in Productivity Growth in Australia. Economic Record, pp. 1860 1939. https://onlinelibrary.wiley.com/doi/abs/10.1111/14754932.12226.

[29] Mat, N. A., Mansur, K. and Mahmud, R. (2015). The Relationship between Human Capital Investment and Economic Development in Sabah. Malaysian Journal of Business and Economics, 2 (1), pp. 83-107.

[30] Nowak, A. and Kijek, T. (2016). The Effect of Human Capital on Labour Productivity of Farms in Poland. Studies in Agricultural Economics, 118 (1), pp. 16-21.

[31] Nurudeen, A. and Usman, A. (2010). Government Expenditure and Economic Growth in Nigeria, 1970-2008: A Disaggregated Analysis. Business and Economics Journal, pp. 1-11. https://www.researchgate.net/publication/284570921_Governm ent_Expenditure_And_Economic_Growth_In_Nigeria_19702008_A_Disaggregated_Analysis.

[32] Fallahi, F., Sakineh, S. and Mehin, A. N. (2010). Determinants of Labor Productivity in Iran's Manufacturing Firms: With Emphasis on Labor Education and Training. MPRA Paper, 27447, University Library of Munich, Germany. https://mpra.ub.unimuenchen.de/27447/1/MPRA_paper_27447.pdf.

[33] Barro, R. (1990). Government Spending in a Simple Model of Endogenous Growth. Journal of Political Economy, 98, pp. 103-125.

[34] Barrel, R. and Pain, N. (1997). Foreign Direct Investment, Technological Change and Economic Growth within Europe. Economic Journal, 107, pp. 243-265.

[35] Kiran, R. and Kaur, M. (2007). Is Liberalization Associated With Higher Productivity? A Case Study of Punjab Manufacturing. The Journal of Business Prospective, 11 (4), pp. 53-66.

[36] Lam, T. D. (2015). A Review of Modern International Trade Theories. American Journal of Economics, Finance and Management, 1 (6), pp. 604-614.

[37] Berggren, N. and Jordahl, H. (2005). Does Free Trade Really Reduce Growth? Further Testing Using the Economic Freedom Index. Public Choice, 122 (1-2), pp. 99-114.

[38] Josheski, D., Lazarov, D. and Koteski, C. (2011). CobbDouglas Production Function Revisited, VAR and VECM Analysis and a Note on Fischer/Cobb-Douglass Paradox. Munich Personal RePEc Archive. https://mpra.ub.unimuenchen.de/33576/, 1-22.

[39] Razmi, M. J. and Refaei, R. (2013). The Effect of Trade Openness and Economic Freedom on Economic Growth: The Case of Middle East and East Asian Countries. International Journal of Economics and Financial Issues, 3 (2), pp. 376-385.

[40] Petrakos, G., Paschalis, A. and Sotiris, P. (2007). Determinants of Economic Growth: The Experts' View, DYNREG Dynamic Regions in a Knowledge Driven Global Economy. Lessons and Policy Implications, EU WORKING PAPERS, No. 20. https://ideas.repec.org/p/esr/wpaper/dynreg20.html. 
[41] Solow, R. (1956). A Contribution to the Theory of Economic Growth. Quarterly Journal of Economics, 70 (1), pp. 65-94.

[42] Brems, H. (1970). A Growth Model of International Direct Investment. American Economic Review, 60 (3), pp. 320-331.

[43] Kida, N. M. (2014). Foreign Direct Investment Environment and Economic Growth. Economica, 10 (4), pp. 31-41.

[44] Smith, A. (1776). The Wealth of Nations. Great Britain: United Kingdom: Edward Elgar Publishing Limited.

[45] Barro, R. (1991). Economic Growth in a Cross Section of Countries. Quarterly Journal of Economics, 106 (2), pp. 407-443.

[46] Barro, R. J. (1996). Determinants of Economic Growth: A Cross Country Empirical Study. National Bureau of Economic Research, (NBER) Working Paper, 5698, 1050 Massachusetts Avenue Cambridge, $\quad$ MA 02138. https://www.nber.org/papers/w5698.
[47] Lahouij, H. (2016). Does Governance Matter to Economic Growth? Evidence from MENA Countries. Awards for Excellence in Student Research and Creative ActivityDocuments 5. http://thekeep.eiu.edu/lib_awards_2016_docs/5.

[48] Greene, W. H. (2002). Econometric Analysis (Fifth Ed.). New Jersey: Prentice Hall.

[49] Bolaky, B. and Freund, C. (2006). Trade, Regulations, and Growth. Conference on Trade and Growth. Research Department. Hosted by the IMF, pp. 1-42. https://www.imf.org/external/np/res/seminars/2006/trade/pdf/f reund.pdf.

[50] Huchet-Bourdon, M., Le Mouel, C. and Vijil, M. (2018). The Relationship between Trade Openness and Economic Growth: Some New Insights on the Openness Measurement Issue. The World Economy, 41 (1), pp. 59-76. 